\title{
An unusual cause of limp
}

\author{
Mehdi Garbash, ${ }^{1}$ Vidhooshni Rajamoorthy, ${ }^{1}$ Shrinavas Tambe, ${ }^{1}$ John Schofield, ${ }^{2}$ Nikila Pandya ${ }^{3}$
}

${ }^{1}$ Department of Paediatrics, Maidstone Hospital, Maidstone, UK;

${ }^{2}$ Histopathology Department, Maidstone Hospital, Maidstone, Kent, UK;

${ }^{3}$ Department of Paediatrics, Maidstone and Tunbridge Wells, Kent, UK

Correspondence to Dr Mehdi Garbash, mehdigarbash@doctors.org.uk

\section{Summary}

Limp is a common clinical presentation in children, seen both in acute and community practice. The incidence is thought to vary between countries with suggested figures between 1.5 and 3.6 cases of non-traumatic limp per 1000 children. The authors present a case of a 6 -yearold girl who attended our accident and emergency department with limp. It has been suggested that the most common diagnoses in our patient's age group are transient synovitis, septic arthritis, osteomyelitis, Perthe's disease and fractures or soft tissue injuries. Surprisingly our patient was diagnosed with haemophagocytic lymphohistiocytosis, for which limp is not a recognised presenting feature.

\section{BACKGROUND}

Limp is a common clinical presentation in children, seen both in acute and community practice. All paediatric, emergency care, orthopaedic and general practice physicians will see these cases. There are a number of causes, with a varying degree of severity and subsequent sequelae. The incidence is thought to vary between countries with suggested figures between 1.5 and 3.6 cases of non-traumatic limp per 1000 children. $^{1}$

As authors, we feel that this case highlights the need to consider a full differential diagnosis, even when the presenting complaint is common. It also highlights the benefit of re-assessing a patient in the light of investigation results and clinical progress, and revisiting the appropriateness of the diagnosis that has been made. The presenting clinical features in this case are also rare for the diagnosis made.

\section{CASE PRESENTATION}

We present a case of a 6-year-old girl who attended our accident and emergency department with limp. She had also experienced 3 days of right knee pain. The pain was reported as being severe, intermittent and had been associated with a fever, confusion and visual hallucinations. Four days prior she had fallen, with evidence of bruising on both her knees. She was otherwise well with no significant medical history or any relevant family history.

Clinical examination revealed a right-sided antalgic gait. There was no abnormality of her hip or knee joints, with no swelling, erythema or tenderness. She had a full range of movement in all other joints. Neurological and vascular examinations were unremarkable. No abnormalities were found on the rest of her examination.

Admission blood parameters showed a haemoglobin of $11.6 \mathrm{~g} / \mathrm{dl}$, white cell count (WCC) of $4.6 \times 10^{9} / 1$, platelets of $182 \times 10^{9} / 1$, C reactive protein (CRP) of 31 and erythrocyte sedimentation rate (ESR) of 94 . Plain $\mathrm{x}$-rays were taken and reported as normal. Osteomyelitis was suspected and our patient therefore underwent a bone scan which found an area of abnormal uptake in the right distal femur involving the medial femoral condyle and etaphysic on both sides of the medial growth plate (figure 1). These findings were consistent with our clinical suspicion. Subsequently, intravenous benzylpenicillin and flucloxacillin were commenced. Over the following days she remained afebrile, began to mobilise with no sign of a limp and returned to normal activities. Reassuringly, she had normal plain x-ray films on day 7 and inflammatory markers improved (ESR 62, CRP 1). Her blood culture was negative.

On day 15 of treatment our patient became unwell with high temperature $\left(38.7^{\circ} \mathrm{C}\right)$ and developed a generalised blanching maculopapular rash over her trunk. Repeat blood counts now revealed a leucopenia, neutropenia and thrombocytopenia ( $\mathrm{Hb} 14.3$, WCC $1.33 \times 10^{9} / 1$, platelets $129 \times 10^{9} / 1$, mean corpuscular volume 79.7 , neutrophils $0.88 \times 10^{9} / 1$, lymphocytes $\left.0.35 \times 10^{9} / 1\right)$. Her inflammatory

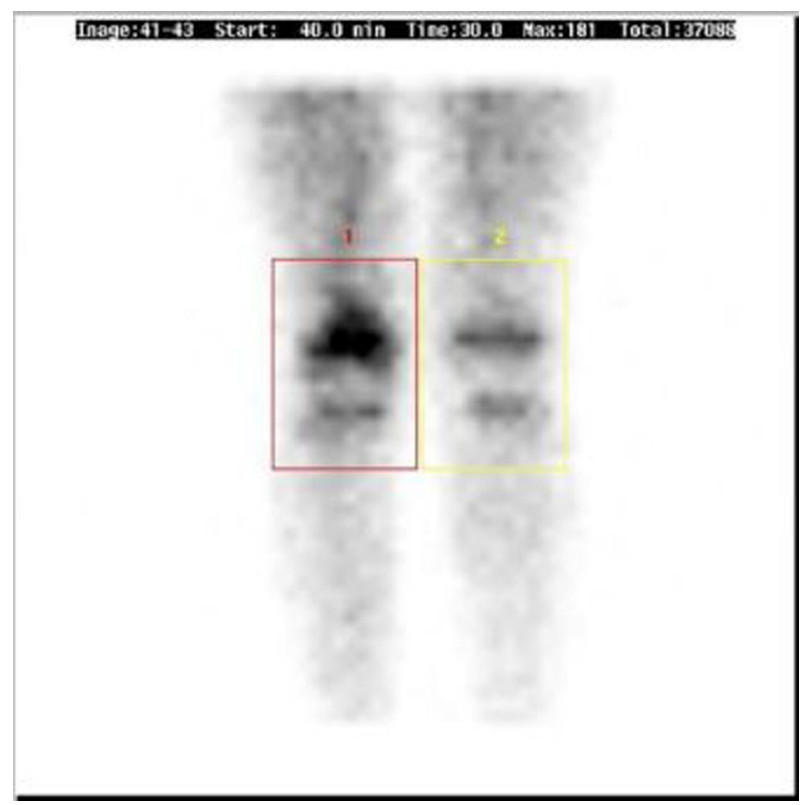

Figure 1 Bone scan showing area of abnormal uptake in right distal femur. Involves the medial femoral condyle and metaphysis on both sides of the medial growth plate. 


\section{BMJ Case Reports}

markers were now CRP of 30 and ESR of 100. Liver function testing revealed an alkaline etaphysic of 225 , aspartate transaminase 447 and she had a lactate dehydrogenase over 6000 . Serum ferritin was raised $(58558 \mu \mathrm{g} / \mathrm{l})$ and cholesterol was 4.7.

A subsequent MRI examination revealed marrow oedema in the medial aspect of the femoral etaphysic and the epiphysis, as well as a small focal collection within the physeal space (figure 2). We therefore arranged to sample the collection and perform a bone marrow examination. Bone marrow histology revealed normocellular fragments and trails, with active trilineage haematopoiesis and mild eosinophilia. Prominent haemophagocytosis was noted, consistent with a diagnosis of haemophagocytic lymphohistiocytosis (HLH) (figure 3). No evidence of parasitic or other infective aetiology was found in bone marrow.

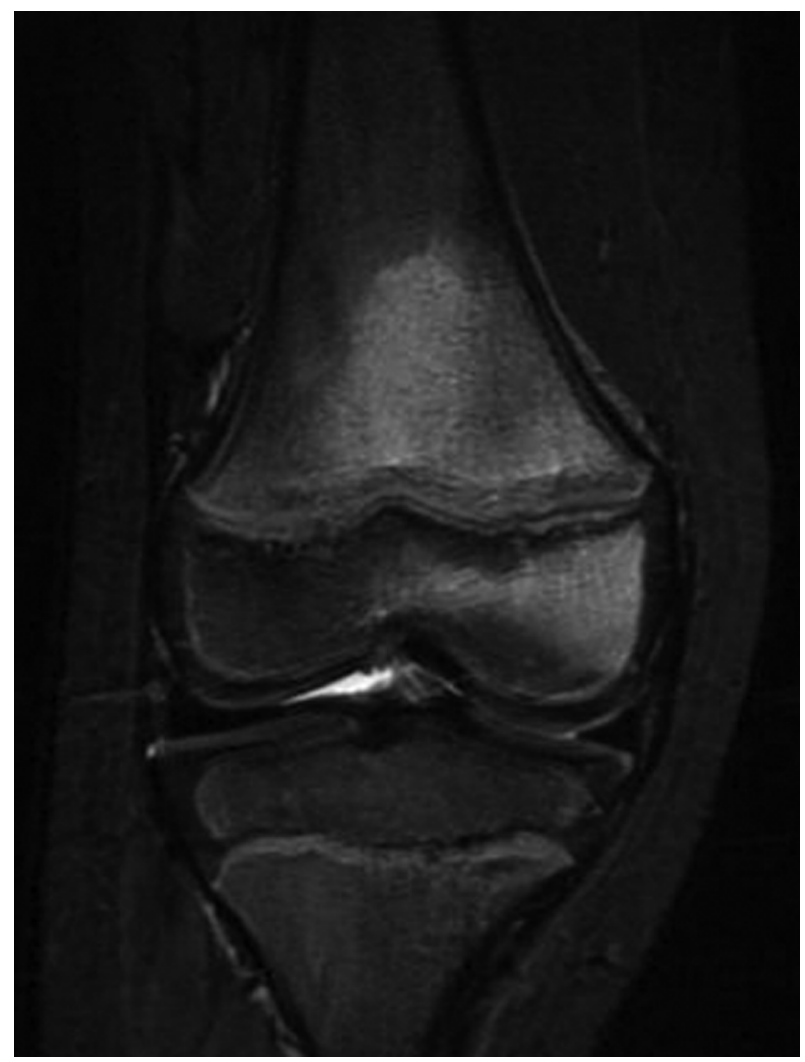

Figure 2 MRI image showing marrow oedema in the medial aspect of the femoral metaphysis and the epiphysis.

\section{TREATMENT}

Our patient was subsequently transferred to our regional oncology centre and received an 8 week course of etoposide and dexamethasone as per the HLH - 2004 treatment protocol. ${ }^{2}$ MRI head was normal. Serological bloods were positive for parvovirus B19 infection which could have been the initial trigger.

\section{OUTCOME AND FOLLOW-UP}

Our patient has completed treatment with no recurrence to date.

\section{DISCUSSION}

Although limp is a common clinical presentation in childhood, HLH does not feature highly on the list of differential diagnoses to be considered at presentation. It has been suggested that the most common diagnoses in our patients age group are transient synovitis, septic arthritis, osteomyelitis, Perthe's disease and fractures or soft tissue injuries. ${ }^{1}$

HLH was first described in 1952 using the name familial haemophagocytic reticulosis where an overgrowth of histiocytes and phagocytosis was described in two related cases, with multisystem involvement. ${ }^{2}$ Although the term

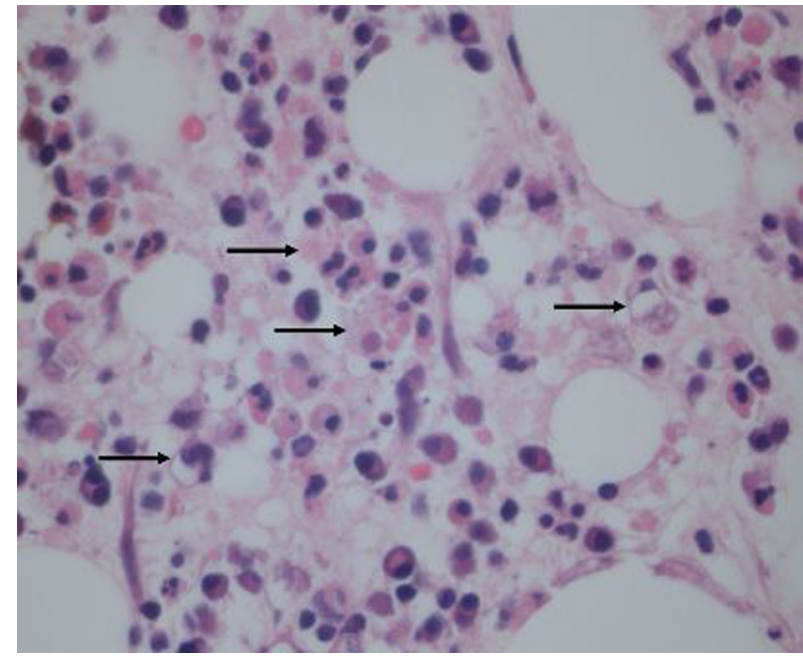

Figure 3 Bone marrow trephine biopsy showing multiple foci of large histiocytes with prominent haemophagocytosis (arrows). Residual haematopoiesis is reduced. There is an excess of plasma cells and eosinophil precursors. (H\&E stain: $x 40$ original magnification).

\section{Table 1 Diagnostic criteria for HLH}

Diagnostic criteria fulfilled if 1 or 2 satisfied:

1 - molecular diagnosis consistent with $\mathrm{HLH}$

$2-5 / 8$ of following criteria to satisfy diagnosis

Fever

Splenomegaly

Cytopenias in at least two cell lineages in peripheral blood

Hypertriglyceridaemia and/or hypofibrinogenaemia Haemophagocytosis in bone marrow or spleen or lymph node Low/absent NK cell activity

Ferritin $\geq 500 \mu \mathrm{g} / \mathrm{l}$

Soluble CD25 (IL-2 receptor $\geq 2400 \mathrm{U} / \mathrm{ml}$ )

Haemoglobin $<9(<10$ in neonates); Platelets $<100 \times 10^{9} /$; Neutrophil $<1 \times 10^{9} / 1$

Fasting triglycerides $\geq 3.0 \mathrm{mmol} / \mathrm{l}$; Fibrinogen $\leq 1.5 \mathrm{~g} / \mathrm{l}$

No evidence of malignancy 
HLH represents a spectrum of disease it is characterised by the haemophagocytosis of blood cells by activated macrophages and monocytes that can often be demonstrated in the bone marrow, liver, spleen or central nervous system (CNS) of its sufferers. ${ }^{2-5}$ HLH is now described as a multi-system disorder that involves the dysregulation of the patients immune system, with the subsequent production of high levels of cytokines and evidence of inflammation. ${ }^{2}{ }^{3}$ Interferons, interleukins and tumour necrosis factor are found at high levels and probably account for the activation of phagocytes as well as some of the subsequent clinical manifestations related to an ineffective and poorly controlled immune system. ${ }^{3}$

HLH is classified as primary or secondary. Primary HLH is either familial or sporadic in nature. The familial type being associated with defects in particular genes (such as PFR1, STX11, STXBP2 and UNC13D) and the sporadic with underlying disorders of the immune system (such as Chediak Higahsi syndrome and X linked lymphoproliferative disorder). ${ }^{2-4}$ Secondary HLH is said to occur following a range of infectious triggers (bacterial, viral and fungal have all been implicated), some malignancies (particularly $\mathrm{T}$ cell lymphoma and leukaemias), immune suppression, autoimmune conditions (like juvenile idiopathic arthritis), after prolonged total parenteral nutrition use and some rare metabolic conditions (eg, lysinuric protein intolerance). ${ }^{2} 35$

The clinical features of HLH can include fever, rash, lympadenopathy, hepatosplenomegaly, jaundice and oedema. Limp has not been reported in the literature to our knowledge. It is hoped that the presence of splenomegaly and cytopenias would alert the clinician. Diagnostic criteria have been developed (table 1), although signs and symptoms can manifest late in the presentation (adapted from $^{346}$ ). The serum ferritin in our patient of $58558 \mu \mathrm{g} / 1$ was a particularly important finding as it has been found that levels above $10000 \mu \mathrm{g} / \mathrm{l}$ were highly sensitive and specific for a diagnosis of HLH in a review of paediatric patients $^{7}$

Treatment for all forms of HLH involves chemotherapy which in the UK follows the HLH-2004 protocol. ${ }^{3}$ Eight weeks of initial treatment with etoposide and corticosteroidsmay be curative in secondary HLH, but may need to be followed by continuation therapy as well as intrathecal treatment for CNS disease. Other options such as allogenic stem cell therapy and immunotherapy have been shown to be beneficial with stem cell transplant offering the possibility of cure in cases of primary HLH.

\section{Learning points}

- Limp is a common clinical presentation in paediatrics, although these cases present to orthopaedics, emergency medicine and general practice.

- It is important to re-assess and re-evaluate clinical diagnoses in the light of investigation results and clinical progress.

- Limp has not been reported as a presenting feature of $\mathrm{HLH}$.

- HLH can be treated with a relatively short course of chemotherapy.

\section{Competing interests None.}

Patient consent Obtained.

\section{REFERENCES}

1. Perry DC, Bruce C. Evaluating the child who presents with an acute limp. BMJ 2010;341:c4250.

2. Freeman HR, Ramanan AV. Review of haemophagocytic lymphohistiocytosis. Arch Dis Child 2011;96:688-93.

3. Histiocyte Society. Treatment Protocol of the second International HLH Study, 2004.

4. Fisman DN. Hemophagocytic syndromes and infection. Emerging Infect Dis 2000;6:601-8.

5. Pritchard J, Broadbent V. Histiocytosis-an introduction. Br J Cancer Supp/ 1994;23:S1-3.

6. Henter JI, Horne A, Arico M, et al. HLH-2004: diagnostic and therapeutic guidelines for haemophagocytic lymphohistiocytosis. Pediatr Blood Canc 2007:48:124-31.

7. Allen CE, Yu X, Kozinetz CA, et al. Highly elevated ferritin levels and the diagnosis of hemophagocytic lymphohistiocytosis. Pediatr Blood Cancer 2008;50:1227-35.

This pdf has been created automatically from the final edited text and images.

Copyright 2012 BMJ Publishing Group. All rights reserved. For permission to reuse any of this content visit http://group.bmj.com/group/rights-licensing/permissions.

BMJ Case Report Fellows may re-use this article for personal use and teaching without any further permission.

Please cite this article as follows (you will need to access the article online to obtain the date of publication).

Garbash M, Rajamoorthy V, Tambe S, Schofield J, Pandya N. An unusual cause of limp. BMJ Case Reports 2012;10.1136/bcr.11.2011.5229, Published XXX

Become a Fellow of BMJ Case Reports today and you can:

- Submit as many cases as you like

- Enjoy fast sympathetic peer review and rapid publication of accepted articles

- Access all the published articles

- Re-use any of the published material for personal use and teaching without further permission

For information on Institutional Fellowships contact consortiasales@bmjgroup.com

Visit casereports.bmj.com for more articles like this and to become a Fellow

Keep up to date with all published cases by signing up for an alert (all we need is your email address) http://casereports.bmj.com/cgi/alerts/etoc 